\title{
On Poetic Types or On More?
}

\author{
Bohumil Fořt
}

\begin{abstract}
Otakar Zich's On Poetic Types (1917-1918) represents not only an early contribution of his to the field of art theory in general and poetics in particular, but it also embodies important evidence documenting the process of the development of the author's theoretical views and interests. As such, the concrete ideas present in the study more or less directly correlate with Zich's later contributions to the fields of theatre and drama studies as well as semiotics and aesthetics. The ideas in On Poetic Types, however, also mirror the wider theoretical and methodological context of a particular period and stage of research. As such, Zich's suggestions can also be compared to ongoing and further developments within his fields of interest.
\end{abstract}

\section{Key words}

structuralism, semiotics, aesthetics, poetry, poet 
Although overshadowed by Otakar Zich's other works, On Poetic Types (1917-1918) is part and parcel of Zich's general and broadly articulated goal of describing various arts along with the components and tendencies of each in a unified and systematic way, a trajectory which culminates mainly in his analyses of drama and theatre. The study also represents an interesting contribution to the development of Czech scholarly thought on literature at the beginning of its early emancipation stage. Let us now try from our contemporary view to show the connection between the study in question and Otakar Zich's later theoretical oeuvre, as well as the work's relationship with important theoretical and methodological achievements in the connected contexts.

The now well-known claim that Zich's work embodies an important transition in the tradition of Czech poetics and aesthetics became especially popular when his work was used by Czech thinkers in order to delineate and specify Czech structuralist thought. A number of scholars view Zich's work in the context of the development of semiotics along with other domestic tendencies which came to form some of the key concepts and strategies of the Prague Structuralist School (Jan Mukařovský, Oleg Sus, Ivo Osolsobě). Some of the representatives of this movement referred to Zich's writings in order to counter the claim that Czech structuralist thought was merely a by-product or post-product of Russian Formalism (Jan Mukařovský, Oleg Sus). A number of commentators value Zich's contribution to modern Czech aesthetic thought, yet take a rather sceptical position with regard to his role in the development of Czech structuralist thought (STEINER 1984). ${ }^{1}$

Traditionally, On Poetic Types is considered an important step in the development of Zich's general aesthetic system, a bridge connecting his interest in music and theatre and complementing his global view of the arts:

The inner connection between aesthetics of music and poetics can be declared by Zich's Aesthetic Perception of Music and On Poetic Types. Psychologically-semantic and typological investigation, first present in an analysis of aesthetic perception of music, creates a hierarchical investigative model used by Zich for designing the layout of the researched material as well as for the development of strategies employed in his aesthetic inquiry, and in addition this investigation is applied to a new material and undertakes a transformation. In this way, the original model is shifted and literary critical base is created. (SUS 1992: 46)

1 Some of the claims supporting the view of Otakar Zich's role in the establishment of Czech structuralist thought are based on his personal and scholarly influence upon his pupils and followers, whereas the majority of the supporters of this view point to particular methods, terms and strategies, as we will see, and connect them with the theory and practice of Czech structuralism. Nevertheless, it is important to emphasize that still other scholars are convinced that there is not much of a general connection between the two methodologies, for example Peter Steiner claims that: 'Zich's aesthetics was static, non-dialectical, and a-historical. It took as its starting point the experience of a single subject, and hence focused on the individual and on psychology. [...] Despite the chronological progression from Zich to Mukařovský, the transition from psychological to Structural aesthetics was a radical theoretical break, a shift into an incompatible disciplinary paradigm' (STEINER 1984: 528). 
Representing an attempt at a systematic classification and typology of poetry, the volume On Poetic Types can be linked to his other works through the crucial concept of the (semantic) image ${ }^{2}$ (významová prédstava) which results from the perception of a piece of art. However, Zich never rigidly defined 'semantic image' and used it instead as a set and generally understood term. ${ }^{3}$ Zich had already used the term in The Aesthetic Perception of Music (1910) and it represents a crucial concept in Zich's major theatrological contribution in The Aesthetics of Dramatic Art (1931). In both studies Zich uses the concept with regard to the specificity of the types of arts to which it is devoted. Nevertheless, in On Poetic Types Zich modifies the term to pure 'image'. Taking 'image' as the basis and framework of his theoretical approach, Zich develops a unique system of the typology of both poetry and poets, using this framework for an aesthetic analysis of poetic art. And it is especially the notion of the (semantic) image through which Oleg Sus sees the most important connection between Zich's On Poetic Types and the further specific development of Czech structuralist thought: 'Theory of "image", which Zich established and articulated firstly on the basis of musical material [...] occupies an important position in the genesis and development of artistic terminology that was consequently elaborated on by Czech structuralism for all kinds of arts' (SUS 1992: 5). ${ }^{4}$

Having emphasized the polysemy of the word poetic, e.g. referring to poetry as well as to poets, in the very first paragraph of On Poetic Types Zich uses this ambiguity as a general theoretical framework for the whole study and assures the reader of his intention to examine poetry in firm relation to its creator, the poet. Zich also simultaneously and explicitly states that this bond is of a psychological nature: 'The relationship between poets and poems is a psychological one. A spiritual dimension of the poet models several levels of their works and the works do declare some of the features of the poet's soul' (ZICH 2003: 167). Consequently, when preparing the field for his own typology of poets, Zich maps existing typologies, which he then, unsurprisingly, rejects. He calls instead for a new typology, which must be based first and foremost on contemporary approaches in psychology. Therefore, poets must now be divided according to imaginative types, with the general classifications being visual, acoustic, and motoric. In addition, Zich claims that poets not only perceive subject matter with regard to the

2 Oleg Sus considers this crucial term purely a result of domestic tradition and influence: 'Zich's original concept of image is of a specific character. It grows from the domestic base of "concrete formalism" and under the influence of Otakar Hostinský's school' (SUS 1992: 6). Nevertheless, in terms of Zich's 'semantic image' also other inspirational sources are commonly referred to, with the main term being 'Bedeutungsvorstellung', a concept from Johannes Volkelt's System der Ästhetik (1905). The influence of Wilhelm Dilthey and Edmund Husserl are also commonly mentioned in this regard.

3 On a more general level, Oleg Sus considers a certain indeterminacy and vagueness a common feature of Zich's work: 'From the point of view of modern semantics, Zich's terminology is far from being rigid and contains ambiguities and also does not precisely differentiate some of its basic notions' (SUS 1992: 26).

4 Nevertheless, the same Oleg Sus admits that the connection between the notion of the semantic image and further development of Czech structuralism deserves a more thorough elaboration: 'The entity which Zich calls an "image" represents a complex borderline and interdisciplinary phenomenon, which has been elaborated on in many works, which, however, usually only touch upon the phenomenon, and a detailed monograph on this topic is still missing' (SUS 1992: 43). 
type to which they belong, but that the types also determine the ways in which they reason and create.

After stipulating the general poetic types, that is, the types of poets, Zich then focuses on the phenomenon of aesthetic delight and its connection with poetry and poems. Zich states that in order to begin an analysis of aesthetic delight evoked by poetry, it is necessary to begin by defining not only the content of the poem but also the mode of its presentation. Zich's reasoning is this: 'By a "poem” I understand a poem spoken, declaimed, narrated, etc., that is a poem's true existential form' (ZICH 2003: 170-171). In the next step, Zich differentiates between qualities relevant to a poem and qualities relevant to its declamation and states that: 'All qualities are demonstrated through declamation; however, some of them are directly determined by the poem and therefore they are just performed by a performer' (ZICH 2003: 171). As a result of this division, Zich is able to provide the reader with a list of specific phonic qualities appropriate to a poem, such as speech sound, rhythm, as well as those appropriate to its declamation, namely strength, tempo, melody, sound, and rhythm tone.

An important part of this analysis of aesthetic delight is devoted to its components, which at a general level consist of content (obsah) and atmosphere (nálada), and can be divided into three main types according to causality: (i) perception (sensorial factor), (ii) our mind's immediate reaction to our perception (immediate reproductive factor), and (iii) the result of the activity of the previous factor (mediated reproductive factor).

Perception, according to Zich's taxonomy, is firmly bound to speech sound along with speech rhythm - these two factors have the ability to initiate the process of further comprehension: for those who understand the language (code) of a poem 'particular sets of sounds and syllables are marks for particular representations or even concepts' (ZICH 2003: 192). These representations, that is, immediate mental reactions to words, together with the words themselves create sense and are bound to the words by pure convention, which is based on experience and learning. Consequently, the sense of words, and also of sentences and larger units, is followed by the mediated representations. As Zich states, poetic language leads to illustrativeness (názornost). Therefore, poems cause general visual, acoustic and also other sensual images.

As a result of his striving to build systemic models, in the next section of his study Zich touches upon the area of aesthetic axiology in his discourse regarding the essential values of poetry and, unsurprisingly, uses the schema he has already developed for analysing components of aesthetic delight. Thus, Zich introduces three sets of these values: (i) phonic and rhythmical (material), (ii) ideal (sense of words and sentences plus the dispositions connected), and (iii) representational (representation based on the sense of words and sentences).

The final section of On Poetic Types is devoted to the typology of poems, with Zich basing his typology on types of poets along with aesthetic elements and values that he has already defined and analysed. Here Zich generally differentiates between verbal, musical, and pictorial (imaginative) poems - again, these types are set not according to an exclusive quality, but according to the one which prevails in a particular poem. 
As we have seen, in his analysis of poetry and poets, Otakar Zich touches upon various themes and uses an assortment of tools in order to deliver a unified and systematic view of the phenomena under investigation. Let us now consider On Poetic Types in the wider theoretical framework of later Czech structuralist thought.

As I have already mentioned, in the detailed analyses by Oleg Sus of Czech aesthetic thought, its development, sources and impact, Sus claims that Zich's system of meaning and its components, although based on a psychological foundation, essentially represents a specific, proto-structuralist semiotic system. Sus connects Zich's work with the general theoretical framework of Czech structuralist thought, here with one claim for all:

In the context of Czech and worldwide aesthetics Zich employs a specific position. On the one hand, he attempts to connect a form analysis with an empirical psychologically-typological investigation containing also a semantic issues sui generis. On the other hand, Zich aims at a structural analysis regarding an aesthetic object; in this particular case he pays his attention to a poetic artwork and its inner immanent qualities. [...] Zich's position can be assigned as pre-structuralist. (SUS 1992: 48-49)

Although Sus and other Czech structuralists often explicitly referred to Zich's thought in their analyses, the connection between Zich's suggestions in On Poetic Types and later structuralist systems does not seem to be unproblematic. Respectively, it is probably easier to recognize only particular specific similarities between these two worlds rather than obvious overlaps.

So, what is structuralist or proto-structuralist about On Poetic Types? In order to at least partially answer this question, I would now like to focus on several concepts and partial systemic possibilities that stem from Zich's work on poetry and poets. These appear, to a higher or lesser degree, to correspond with certain structuralist patterns.

First is the notion of poetic language - a notion which explicitly connects Zich's work with the traditions of Russian Formalism and Czech Structuralism. Poetic language in Zich's system of poetry analysis plays at least two important roles, which I will henceforth refer to general semiotic and particular semantic-pragmatic.

There is probably no evidence to suggest that while writing his study Zich was familiar with de Saussure's Course de linguistique générale (which was published in 1916, after Saussure's death). Any knowledge of Saussure's Course was most likely brought to Prague by Sergej Karcevskij, de Saussure's former student who represents the source of the knowledge from the Geneva School to the Prague Linguistic Circle, thus it seems that in one aspect of his reasoning Zich directly and rigidly stipulates a complete arbitrariness of language and its units prior to his knowledge of Saussure's work.

Referring to the relationship between ordinary and poetic language, Zich makes a random comment about the essence of language, stipulating that: 'Human language, which serves as material for poetic artworks, has two sides: sound and meaning. Both are firmly bound to each other and cannot be separated without damaging this bond: this is a psychological reality' (ZICH 2003: 209). Obviously, in this statement Zich is 
not saying anything other than that the connection between sound and meaning is of a psychological essence; nevertheless, elsewhere the same author connects notion and sense in a word in the following way:

Images which represent the sense of a word are collected through experience, which starts form early childhood. Of course, the process differs from the process of recollection: various sensual images [...] are connected with particular 'words' and the tie between the word and the image is strengthened through repetition to the extent that the connection is considered absolutely natural and necessary. However, this connection is of a purely conventional nature. (ZICH 2003: 192)

At this point, I believe it is up to the readers to decide whether they want to equate Zich's image and sense with de Saussurian signifier and signified, or that the connection is too vague. At any rate, the psychological dimension along with the notion of the arbitrariness of language explicitly and implicitly present in Zich's reasoning indicate that it is at least worth a try.

Nevertheless, it should be emphasized that it is the concept of image which has provoked semioticians to claim that this notion actually did play an important role in establishment of the semiotic dimension of the future structuralist thought of the Prague School. The main supporter of this idea, Ivo Osolsobě even refers to Otakar Zich as a 'latent semiotician':

Although Zich never connected his thought with the notion of sign (which has always had a very indeterminate content in non-linguistic disciplines, and therefore it was understood more as a signal than a notion), and although he never spoke about semiotics, is a semiotician. [...] Otakar Zich, who never demarcated semiotics as a field of his scholarly program, actually did fulfil this program. (OSOLSOBĚ 1981: 38-39)

'The difference between poetic, every-day, and scientific language is its atmosphere' (ZICH 2003: 193). This statement has serious consequences at least for two semantically-pragmatic aspects of Zich's system. First of all, the concept of atmosphere, which is a quality, as we have seen, that is associated with every component of aesthetic delight, seems to be present at all levels of a poem's semantics. Atmosphere appears together with sense, following the principle of compositionality: 'To achieve a unified atmosphere is first of all the poet's task. Each of the components has its own atmosphere and the poet has to choose the components so that they partially agree with each other and merge in the final unity' (ZICH 2003: 206). So, it seems that atmosphere is, together with content, present at every level of the semantic build of a poem (word - sentence - poem), and represents a phenomenon which complements content and which, I believe, in later structuralist thought is close to such terms as accessory meaning or even connotation. In addition, when Zich further states that: 'The reason that the global impression of a poem is not colourful but unified is caused by a unified atmosphere of these components' (ZICH 2003: 206), and I hope that this is not too far from sound 
reasoning. It is possible to see atmosphere(ness) in some aspects of what became the later structuralist concept of semantic gesture. If so, and here again I express merely my own belief, the gate to pragmatics seems to be fully opened.

And indeed, performance, which embodies one of the essential leitmotifs throughout Zich's work, plays a crucial role in the process of aesthetic communication. In terms of On Poetic Types, the performative part of the process is declamation. For Zich, declamation as a specific form of a performative act represents an important bind between the work and its receiver. Indeed, introducing declamation as an important part of a literary artwork's aesthetic analysis enables Zich to move away from a mere analysis of the artwork itself. Instead it allows a communicative dimension to be attributed to the work. By focusing on the performative part of literary aesthetic communication, Zich essentially invites the receiving subject into the play: 'Poetic language lends itself to imaginativeness (názornost), e.g. it strives to enable the receiver to recollect the image belonging to the sense of a word or sentence, in the clearest way possible. [...] The success depends on the character of the words chosen by the poet and on the way they are used' (ZICH 2003: 199). Though not yet in the form of the balanced communication model that was later used as the theoretical axiom of the Prague School's aesthetics as well as the systematic aesthetic conception of reader-response, Zich's contribution, as we can see, represents an important pre-structuralist attempt to accommodate the receiver of the aesthetic communication into a unified aesthetic system. It may be needless to emphasize that such approaches provide us with a fruitful by-product by opening the door to a thorough analysis of aesthetic artefacts and their impacts.

For the purpose of my concise comparison of some of Otakar Zich's concepts with those of the Prague structuralists I have chosen the idea of poetic language and its related contexts. Nevertheless, it must be emphasized that this comparison is only one of the many to be made using On Poetic Types thanks to the great fecundity of ideas that the work offers. Other comparative studies on concepts such as phonic patterning, subjects of aesthetic communication, defamiliarization, as well as in the area of aesthetic analyses of particular literary artworks could certainly be conducted. At the same time, it is important to view On Poetic Types as one of the first milestones of Otakar Zich's theoretical work, an oeuvre which culminates in his invaluable systemic aesthetics of dramatic art.

\section{Bibliography}

OSOLSOBĚ, Ivo. 1981. Sémiotika Otakara Zicha [Otakar Zich's Semiotics]. In Rudolf Pečman (ed.). Vědecký odkaz Otakara Zicha [Otakar Zich's Scientific Legacy]. Brno: Česká hudební společnost, 1981: 37-52.

STEINER, Peter. 1984. Production versus Reception: The Esthetic Axiologies of Otakar Zich and Jan Mukařovský. In Benjamin A. Stolz, I. R. Titunik and Lubomír Doležel (eds.). Language and Literary Theory: In Honor of Ladislav Matejka. Ann Arbor: University of Michigan, 1984: $527-534$. 
SUS, Oleg. 1992. Geneze sémantiky hudby a básnictvi v moderni české estetice. Dvě studie o Otakaru Zichovi [The Genesis of Musical and Literary Semantics in Modern Czech Aesthetics. Two Studies on Otakar Zich]. Brno: Filozofická fakulta Masarykovy university, 1992.

ZICH, Otakar. 2003 [1918]. O typech básnických [On Poetic Types]. In Jiří Kudrnáč (ed.). Česká literárni kritika v dotyku se strukturalismem [Czech Structuralist Literary Criticism]. Brno: Host, 2003: 167-230.

\section{prof. PhDr. Bohumil Fořt, Ph.D.}

Department of Linguistics and Baltic Languages,

Faculty of Arts, Masaryk University,

Jaselská 201/18, 60200 Brno, Czech Republic

fort@ucl.cas.cz

Bohumil Fořt is a professor of literary theory at Masaryk University (Brno) and a senior researcher at the Czech Academy of Sciences (Prague). He studied and has taught at Charles University in Prague, The University of Toronto, and University College London. He is the author of five monographs focused on fictional worlds theory (An Introduction to Fictional Worlds Theory, 2016), literary character, the Prague School, Czech realist prose, as well as some fifty studies published in Czech and English; he also translates scholarly books and articles from English into Czech (L. Doležel, T. Pavel, J. Pier, M.-L. Ryan, D. Herman, B. Richardson). His main fields of interest are literary theory and its history, narrative theory, literary realism, structuralism, semiotics, history of Czech literature, and fictional worlds theory. 